\title{
Filigrane
}

Écoutes psychothérapiques

\section{Départ de Hélène Richard}

\section{Hélène Richard}

Volume 18, numéro 1, printemps 2009

Le corps. Sur le divan. Dans le fauteuil I

URI : https://id.erudit.org/iderudit/037715ar

DOI : https://doi.org/10.7202/037715ar

Aller au sommaire du numéro

Éditeur(s)

Revue Santé mentale au Québec

ISSN

1192-1412 (imprimé)

1911-4656 (numérique)

Découvrir la revue

Citer ce document

Richard, H. (2009). Départ de Hélène Richard. Filigrane, 18(1), 4-4.

https://doi.org/10.7202/037715ar d'utilisation que vous pouvez consulter en ligne.

https://apropos.erudit.org/fr/usagers/politique-dutilisation/ 


\section{Départ de Hélène Richard}

Quand les années se suivent et commencent à se ressembler, il est temps de partir... Pour cette raison, j' annonce aux lecteurs de Filigrane mon départ du poste de rédactrice en chef de la revue à partir de septembre 2009. Cofondatrice de Filigrane, parue pour la première fois en 1992, j'ai éprouvé beaucoup de fierté et de satisfaction à contribuer pendant près de vingt ans à la transmission de la psychanalyse au Québec.

Ce travail s'est effectué dans le plaisir, grâce à la complicité d'une succession de collègues au sein du comité de rédaction, de même que de collaborateurs et d'auteurs sans lesquels Filigrane ne pourrait subsister.

Afin de poursuivre d'autres projets, je laisse mon poste entre les mains fines, intelligentes et compétentes de Mesdames Sophie Gilbert et Véronique Lussier, membres actuels du comité et professeures au département de psychologie de l'UQAM. Elles seront secondées efficacement par les autres membres présentement en poste: Mesdames Danièle Doiron, Thérèse Nadeau, France Sénécal.

Je quitte une revue en expansion, au budget enfin équilibré, des collègues que je regretterai et à qui je confie le soin d'insuffler à Filigrane une nouvelle vie, à leur image, et d'ainsi en assurer la pérennité.

Hélène Richard 